\title{
Tingkat Pengetahuan Bahaya Merokok bagi Kesehatan Gigi Mulut pada Siswa SMK Negeri 8 Manado
}

\author{
${ }^{1}$ Karen Rompis \\ ${ }^{1}$ Vonny N. S. Wowor \\ ${ }^{2}$ Damajanty H. C. Pangemanan
}

\author{
${ }^{1}$ Program Studi Pendiikan Dokter Gigi Fakultas Kedokteran \\ ${ }^{2}$ Bagian Fisiologi Fakultas Kedokteran \\ Universitas Sam Ratulangi Manado \\ Email: krompis@yahoo.com
}

\begin{abstract}
Smoking habit can be found in various age groups, ranging from children to adults. To date, many children and adolescents have become active smokers. Smoking is one of the triggers of oral cavity disorders and it influences aesthetics inter alia discolored teeth, mucosal thickening, gingivitis, and even oral cancer. This study was aimed to determine the level of knowledge about the impact of smoking on oral and dental health among students of SMK Negeri 8 Manado (senior high school). This was a descriptive study with a cross-sectional design, involving 40 respondents obtained by using total sampling method. Data were obtained by using questionnaire covering the characteristics of respondents and their levels of knowledge about the impact of smoking on oral and dental health. The results showed that the level of student knowledge about the impact of smoking on oral and dental health was 543. In conclusion, the level of knowledge of students at SMK Negeri 8 Manado about the impact of smoking on oral health was classified as good.
\end{abstract}

Keywords: knowledge of students, impact of smoking, oral and dental health

\begin{abstract}
Abstrak: Kebiasaan merokok dapat ditemukan pada berbagai golongan usia, mulai dari anakanak hingga dewasa bahkan saat ini banyak anak-anak serta remaja sudah menjadi perokok aktif. Kebiasaan merokok merupakan salah satu pencetus timbulnya gangguan penyakit rongga mulut serta memengaruhi estetika, antara lain dapat mengakibatkan perubahan warna gigi, penebalan mukosa, gingivitis, bahkan kanker mulut. Penelitian ini bertujuan untuk megetahui gambaran tingkat pengetahuan tentang bahaya merokok bagi kesehatan gigi mulut pada siswa SMK Negeri 8 Manado. Jenis penelitian ialah deskriptif dengan desain potong lintang. Terdapat 40 responden penelitian, diambil menggunakan total sampling. Pengumpulan data diperoleh melalui kuesioner yang meliputi karakteristik responden dan tingkat pengetahuan mengenai bahaya merokok bagi kesehatan gigi mulut. Hasil penelitian menunjukkan tingkat pengetahuan siswa tentang bahaya merokok bagi kesehatan gigi mulut memperoleh skor 543. Simpulan penelitian ini ialah tingkat pengetahuan siswa SMK Negeri 8 Manado tentang bahaya merokok bagi kesehatan gigi mulut tergolong baik.
\end{abstract}

Kata kunci: pengetahuan siswa, bahaya merokok, kesehatan gigi mulut

Merokok merupakan salah satu kebiasaan yang sangat umum yang dapat kita temukan di kalangan masyarakat, bahkan bagi golongan tertentu sudah menjadi suatu gaya hidup. Kebiasaan merokok dapat ditemukan pada berbagai golongan usia, mulai dari anak-anak hingga orang dewasa. Saat ini banyak anak-anak serta remaja yang sudah menjadi perokok aktif.

Berdasarkan penelitian yang dilakukan oleh Global Youth Tobacco Survey di Baghdad Irak tahun 2007, terdapat 39,5\% 
remaja laki-laki dan $16,1 \%$ remaja perempuan berusia 13-15 tahun sudah mulai mencoba merokok. ${ }^{1}$ Prevalensi perokok remaja di Indonesia yang berusia 13-15 tahun mengalami peningkatan dari $12,6 \%$ di tahun 2006 menjadi 20,3\% pada tahun 2009. ${ }^{2}$ Data World Health Organization (WHO)tahun 2008 menunjukan Indonesia menduduki peringkat ketiga dengan jumlah perokok terbesar di dunia setelah China dan India. ${ }^{3}$ Data Riskesdas tahun 2010 menunjukkan adanya peningkatan persentase perokok aktif mencapai $67 \%$ pada remaja laki-laki, dan 2,7\% pada remaja perempuan dari jumlah penduduk. ${ }^{4}$ Menurut data Kementerian Kesehatan Republik Indonesia tahun 2013, lebih dari sepertiga pelajar dilaporkan sudah mulai terbiasa merokok. Terdapat tiga di antara sepuluh pelajar menyatakan pertama kali merokok pada usia di bawah 10 tahun. $^{5}$

Merokok memiliki pengaruh besar dalam merusak kesehatan. Menurut WHO rokok ialah penyebab berbagai penyakit pada perokok, baik perokok aktif maupun perokok pasif. ${ }^{6}$ Kebiasaan merokok merupakan salah satu pencetus timbulnya gangguan penyakit rongga mulut serta berpengarunya terhadap estetika, antara lain dapat mengakibatkan perubahan warna gigi, penebalan mukosa, gingivitis, bahkan penyakit kanker mulut. ${ }^{7}$ Rongga mulut merupakan jalan masuk utama untuk makanan, minuman, dan bahan-bahan lain, misalnya rokok. Kandungan rokok yang berupa tembakau, nikotin, karbon monoksida, ammonia, dan derivat-derivat lainnya dapat mengiritasi rongga mulut saat dikonsumsi karena adanya pembakaran. ${ }^{8}$

Penelitian yang dilakukan pada tahun 2016 menunjukan hasil prevalensi perokok dari tahun ke tahun semakin meningkat. Mengonsumsi rokok pada tahap awal tidak dirasakan efeknya, namun lama kelamaan akan muncul berbagai penyakit dalam tubuh perokok, dan menyebabkan timbulnya kondisi patologik di rongga mulut. ${ }^{9}$ Gigi dan jaringan lunak rongga mulut, merupakan bagian yang mengalami kerusakan akibat rokok. Penyakit karies gigi, kebersihan gigi, penyakit periodontal, kehi- langan gigi dan kanker mulut merupakan kasus yang ditemukan pada perokok. ${ }^{10}$

Terdapat beberapa faktor yang melatarbelakangi kebiasaan merokok pada remaja, salah satunya yaitu kurangnya pengetahuan remaja sekarang ini tentang bahaya merokok bagi kesehatan gigi dan mulut. Pengetahuan merupakan domain yang sangat penting bagi pembentukan perilaku seseorang bahkan tindakan serta kebiasaan yang dilakukan. Tingkat pengetahuan remaja tentang kandungan rokok serta dampak dan bahaya yang dapat ditimbulkan pada gigi dan mulut dapat memengaruhi kebiasaan merokok pada remaja. ${ }^{11}$ Hasil penelitian Sairo et $\mathrm{al}^{11}$ mengenai hubungan pengetahuan tentang bahaya merokok pada mahasiswa di Kota Malang menunjukkan tingkat pengetahun yang kurang baik dan sebagian besar tergolong kategori perokok berat.

SMK Negeri 8 Manado merupakan institusi pendidikan yang ada di kota Manado. Berdasarkan pengamatan penulis semasa menjadi siswa, terlihat banyak siswa yang memiliki kebisaan merokok, Bahkan di kantin sekolah banyak siswa maupun siswi yang melakukan kebiasaan merokok. Remaja sebagai generasi penerus bangsa seharusnya mendapatkan pengetahuan lebih tentang berbagai bahaya serta dampak merokok dan apa saja yang menjadi akibat dari suatu kebiasaan merokok; hal-hal tersebut perlu diperhatikan oleh para pengajar. Oleh karena itu, peneliti tertarik untuk mengetahui hubungan pengetahuan bahaya merokok terhadap kesehatan gigi mulut dengan kebiasaan merokok pada siswa SMK Negeri 8 Manado.

\section{METODE PENELITIAN}

Penelitian ini dilaksanakan di SMK Negeri 8 Manado pada bulan Mei tahun 2019. Jenis penelitian ialah deskriptif dengan desain potong lintang. Sampel penelitian ini yaitu siswa perokok di kelas $\mathrm{X}$ sebanyak 40 responden. Kriteria inklusi pada penelitian ini yaitu siswa yang aktif bersekolah di SMK Negeri 8 Manado. Pengambilan sampel penelitian menggunakan metode total sampling. 
Pengetahuan responden meliputi pengetahuan tentang bahaya merokok bagi kesehatan gigi mulut diukur dengan menggunakan kuesioner berisikan 8 pertanyaan yang diberi nilai/skor 2 untuk jawaban Tahu dan nilai/skor 1 untuk jawaban Tidak tahu.

\section{HASIL PENELITIAN}

Responden penelitian ini berjumlah 40 siswa, terdiri dari 33 siswa $(82,50 \%)$ berjenis kelamin laki-laki dan 7 siswa $(17,50 \%)$ berjenis kelamin perempuan. Tabel 1 memperlihatkan karakteristik responden berdasarkan usia. Responden terbanyak berusia 16 tahun (60\%) dan yang paling sedikit berusia 17 tahun (10\%).

Tabel 1. Distribusi frekuensi responden berdasarkan usia.

\begin{tabular}{ccc}
\hline Usia & $\mathbf{N}$ & $\mathbf{\%}$ \\
\hline 15 & 12 & 30,00 \\
16 & 24 & 60,00 \\
17 & 4 & 10,00 \\
Total & 40 & 100,00 \\
\hline
\end{tabular}

Tabel 2 menyajikan distribusi berdasarkan tingkat pengetahuan responden tentang bahaya merokok bagi kesehatan gigi dan mulut.

Berdasarkan hasil perhitungan skor penilaian seluruh responden, tingkat pengetahuan responden tentang bahaya merokok bagi kesehatan gigi mulut memperoleh skor 543. Batas skor terendah dari kelompok pertanyaan ialah 320 , dan skor tertinggi yaitu 640. Gambar 1 memperlihatkan skor hasil perhitungan yang diperoleh yang menunjukkan bahwa tingkat pengetahuan tentang bahaya merokok bagi kesehatan gigi mulut tergolong baik.

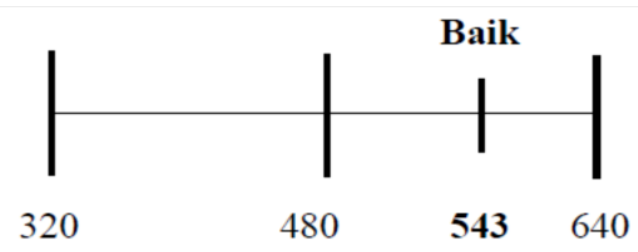

Gambar 1. Tingkat pengetahuan tentang bahaya merokok bagi kesehatan gigi mulut tergolong baik

Tabel 2. Distribusi frekuensi tingkat pengetahuan responden tentang bahaya merokok bagi kesehatan gigi mulut

\begin{tabular}{|c|c|c|c|c|}
\hline \multirow[b]{2}{*}{ No } & \multirow[b]{2}{*}{ Pertanyaan } & \multicolumn{2}{|c|}{ Jawaban } & \multirow[b]{2}{*}{ Skor penilaian } \\
\hline & & Tahu & $\begin{array}{c}\text { Tidak } \\
\text { tahu }\end{array}$ & \\
\hline 1 & $\begin{array}{l}\text { Tahukah anda merokok merugikan } \\
\text { kesehatan? }\end{array}$ & 35 & 5 & 75 \\
\hline 2 & $\begin{array}{l}\text { Tahukah anda asap rokok mengandung zat- } \\
\text { zat yang berbahaya bagi kesehatan? }\end{array}$ & 38 & 2 & 78 \\
\hline 3 & $\begin{array}{l}\text { Tahukah anda merokok dapat menyebabkan } \\
\text { bau mulut? }\end{array}$ & 33 & 7 & 73 \\
\hline 4 & $\begin{array}{l}\text { Tahukah anda merokok berpengaruh pada } \\
\text { kebersihan gigi dan mulut? }\end{array}$ & 32 & 8 & 72 \\
\hline 5 & $\begin{array}{l}\text { Tahukah anda merokok dapat menyebabkan } \\
\text { perubahan warna pada gigi? }\end{array}$ & 28 & 12 & 68 \\
\hline 6 & $\begin{array}{l}\text { Tahukah anda perubahan warna pada gigi } \\
\text { akibat merokok anda disebabkan oleh tar } \\
\text { yang terkandung pada asap rokok? }\end{array}$ & 24 & 16 & 64 \\
\hline 7 & $\begin{array}{l}\text { Tahukah anda merokok dapat menyebabkan } \\
\text { gigi goyang? }\end{array}$ & 13 & 27 & 53 \\
\hline 8 & $\begin{array}{l}\text { Tahukah anda merokok dapat menyebabkan } \\
\text { gusi mudah berdarah? }\end{array}$ & 20 & 20 & 60 \\
\hline & Total skor & & & 543 \\
\hline
\end{tabular}




\section{BAHASAN}

Pengetahuan merupakan hasil tahu seseorang terhadap suatu objek melalui indera yang dimiliki, meliputi indera penglihatan, pendengaran, penciuman, perasa, dan peraba. ${ }^{12,13}$ Novitasari et $\mathrm{al}^{14}$ menyatakan bahwa faktor-faktor yang dapat memengaruhi pengetahuan antara lain, usia, pendidikan, pekerjaan, pengalaman, minat, lingkungan dan informasi.

Dalam penelitian ini perolehan skor tingkat pengetahuan responden tentang bahaya merokok bagi kesehatan gigi mulut termasuk pada kategori baik, yang menunjukkan bahwa hampir seluruh responden memiliki pengetahuan yang baik mengenai dampak merokok bagi kesehatan gigi mulut, dengan tingkat pengetahuan responden mencapai skor 543. Hal ini dapat dipahami karena dewasa ini begitu mudahnya informasi diperoleh masyarakat termasuk responden. Banyaknya iklan tentang bahaya merokok yang terpampang di jalanan umum, serta informasi yang ada di media cetak, media elektronik, maupun media internet dapat menyebabkan responden memiliki tingkat pengetahuan baik.

Terbentuknya pengetahuan responden tentang bahaya merokok bagi kesehatan, juga dapat diperoleh lewat pendidikan nonformal di rumah, karena merupakan hal yang umum orangtua melarang anakanaknya untuk merokok walaupun alas annya bermacam-macam. Pemahaman yang diberikan orangtua di rumah dapat memengaruhi responden. Pelarangan terhadap merokok juga dilakukan di sekolahsekolah, bahkan dewasa ini larangan merokok ditempat umum sudah diberlakukan. ${ }^{15}$ Hal ini juga didukung oleh penelitian yang dilakukan Darajat ${ }^{16}$ pada tahun 2013, tentang pelaksanaan peraturan kawasan bebas asap rokok di tempat-tempat umum sebagai perwujudan hak atas kesehatan masyarakat. Darajat menyatakan bahwa merokok merupakan suatu perilaku yang tidak sehat, selain berbahaya bagi diri sendiri juga berbahaya bagi lingkungan sekitar. Keadaan ini menggambarkan bahwa bahaya merokok sudah diketahui oleh masyarakat secara umum.
Berbagai informasi tentang kesehatan gigi secara umum mudah diperoleh masyarakat termasuk responden dan turut berpengaruh pada pengetahuan yang dimiliki responden. Hal ini dapat dipengaruhi juga oleh tingkat pendidikan responden yang pada penelitian ini ialah siswa SMK, dengan pengetahuan yang sudah terbentuk sejak sekolah dasar. Di samping itu remaja pada kelompok usia ini ditandai dengan kemampuan berpikir yang baru. Rangsangan berupa informasi yang mudah diperoleh akibat kemajuan teknologi di bidang informasi, memengaruhi tingkat pengetahuan responden. Beragam informasi yang diperoleh termasuk informasi tentang bahaya merokok bagi kesehatan gigi mulut turut membentuk pengetahuan responden. Kemudahan dalam memperoleh informasi dapat membantu mempercepat seseorang untuk memperoleh pengetahuan baru. ${ }^{16}$

Usia 15-17 tahun merupakan usia remaja pertengahan. Pada kelompok usia ini remaja memiliki ciri mulai berkembangnya kematangan tingkah laku. Remaja mulai belajar mengendalikan impulsivitas dab membuat keputusan-keputusan awal sesuai tujuan yang ingin dicapai. ${ }^{17}$

Tingginya pengetahuan responden dapat dipengaruhi oleh tingkat intelektual siswa. Hal ini dikarenakan SMK Negeri 8 merupakan sekolah berprestasi dalam bidangnya. Siswa sekolah ini umumnya merupakan siswa yang berprestasi semasa pendididkan di tingkat SMP, sehingga kemampuan yang dimiliki siswa dalam menyerap informasi turut menentukan tingkat pengetahuan yang dimiliki. Namun setelah ditinjau kembali pada hasil penelitian yang ada terdapat keterbatasan peneliti yang kurang memperhatikan alat ukur penelitian yaitu kuesioner berupa pertanyaan yang kurang spesifik pada kesehatan gigi dan mulut sehingga hanya berfokus pada pertanyaan kesehatan mulut secara umum saja. Jadi ketika dilihat kembali pada poin pertanyaan ke-7 dan ke-8, keduanya sangat spesifik tentang kesehatan gigi mulut yang dapat menilai sampai dimana tingkat pengetahuan siswa terhadap bahaya merokok bagi kesehatan gigi mulut. Nilai pada kuesioner 
poin pertanyaan ke-7 yaitu dari 40 responden, 27 orang menjawab tidak tahu dan hanya 13 orang yang menjawab tahu. Pada poin pertanyaan ke 8,20 responden menjawab tidak tahu dan 20 lainnya menjawab tahu. Berdasarkan hasil yang diperoleh jika hanya melihat dua pertanyaan tersebut, dapat disimpulkan bahwa tingkat pengetahuan siswa tentang bahaya merokok bagi kesehatan gigi mulut masih dibawah ratarata atau bisa dikatakan kurang,

\section{SIMPULAN}

Berdasarkan hasil penelitian ini dapat disimpulkan bahwa tingkat pengetahuan siswa SMK Negeri 8 Manado tentang bahaya merokok bagi kesehatan gigi mulut tergolong baik.

Perlu dilakukan penelitian sejenis lebih lanjut untuk meneliti hubungan antara kebiasaan merokok dengan beberapa gangguan kesehatan gigi mulut yang diperkirakan merupakan dampak dari merokok. Selain itu, data hasil penelitian dapat dimanfaatkan oleh pihak puskesmas dalam berbagai program preventif dan promotif guna meningkatkan derajat kesehatan gigi mulut

\section{DAFTAR PUSTAKA}

1. Albedah AM, Quershi NA. The global youth tobacco survey: 2001-2002 in Riyadh region, the Kingdom of Saudi Arabia. Subst Abuse Rehabil. 2011;2:197-204.

2. WHO report on the global tobacco epidemic. Geneva, WHO, 2015.

3. Badan Penelitian dan Pengembangan Kesehatan. Riset Kesehatan Dasar (RISKESDAS) 2007. Jakarta: Kementerian Kesehatan Republik Indonesia, 2008; p. 130-40.

4. Kementerian Kesehatan Republik Indonesia. Anak remaja rentan menjadi perokok pemula. Jakarta: Kementerian Kesehatan RI, 2013.

5. Komalasari D, Helmi AF. Faktor-faktor penyebab perilaku merokok pada remaja. Jurnal Psikologi. 200;1:37-47.

6. Husodo SM. Jumlah leukosit air ludah para perokok. Majalah Kesehatan Gigi Indonesia. 2015;1(6):18.

7. Natamiharja LB. Kebiasaan merokok dan karies spesifik pada sopir-sopir di medan. Dentika. 2005;6(2):284-5.

8. Ni Nengah Sumerti. Merokok dan efeknya terhadap kesehatan gigi dan mulut. Jurnal Kesehatan Gigi.2016;4(2):48-57.

9. Kusuma ARP. Pengaruh merokok terhadap kesehatan gigi dan rongga mulut. Majalah Ilmiah Sultan Agung. 2019; 49(124):12-19.

10. Triswanto S. Stop Merokok. Yogyakarta: Progresif Books, 2007; p. 18.

11. Sairo BB, Wiyono J, Adi RCW. Hubungan pengetahuan tentang bahaya merokok dengan mengkonsumsi rokok pada mahasiswa (IKAWASBA) di Tlogomas Kota Malang. Nursing News. 2017;2(2):719-27.

12. Notoatmodjo S. Kesehatan Masyarakat Ilmu dan Seni. Jakarta: Rineka Cipta, 2011; p. 135-54.

13. Notoatmodjo S. Promosi Kesehatan Teori dan Aplikasi. Jakarta: Rineka Cipta, 2010. P. 43-62.

14. Novitasari MK, Wowor V, Kaunang WPJ. Gambaran tingkat pengetahuan siswa SMA Negeri 1 Manado tentang dampak merokok bagi kesehatan gigi dan mulut. eG. 2014;2(2):5.

15. Kementerian Kesehatan Republik Indonesia. Pedoman teknis pengembangan kawasan tanpa rokok. Jakarta: Kementerian Kesehatan Republik Indonesia, 2014.

16. Derajat Z. Pelaksanaan Peraturan Kawasan Bebas Asap Rokok pada Tempat Umum sebagai Perwujudan Hak atas Kesehatan Masyarakat. Jakarta: Bumi Aksara, 2008.

17. Kurniati A. Gambaran kebiasaan merokok dengan profil tekanan darah pada mahasiswa perokok laki-laki usia 18-22 tahun. Jurnal Kesehatan Masyarakat. 2012;1(2):251-6 